\title{
Development of maternal and foetal immune responses in cattle following experimental challenge with Neospora caninum at day 210 of gestation
}

Paul M Bartley ${ }^{1 *}$, Frank Katzer ${ }^{1}$, Mara S Rocchi ${ }^{1}$, Stephen W Maley ${ }^{1}$, Julio Benavides ${ }^{1,2}$, Mintu Nath ${ }^{3}$, Yvonne Pang ${ }^{1}$, Germán Cantón ${ }^{1,4}$, Jackie Thomson ${ }^{1}$, Francesca Chianini ${ }^{1}$ and Elisabeth A Innes ${ }^{1}$

\begin{abstract}
This study examined the immunological responses of pregnant cattle and their foetuses following an experimental challenge with live Neospora caninum tachyzoites at day 210 of gestation. Animals were bled prior to and weekly throughout the experiment and sacrificed at 14, 28, 42 and 56 days post inoculation (dpi). At post mortem examination, samples of lymph nodes and spleen were collected from both dam and foetus for immunological analysis. Subcutaneous (sc) inoculation over the left prefemoral (LPF) lymph node of pregnant cattle at day 210 of gestation, led to the vertical transmission of parasites by $14 \mathrm{dpi}$, however no foetal deaths were observed in the infected animals. Foetuses from infected dams mounted Neospora-specific humoral and cell-mediated immune (CMI) responses by $14 \mathrm{dpi}$. These responses involved anti-Neospora lgG, antigen-specific lymphocyte proliferation, and the production of the cytokines IFN- $\gamma$, interleukin (IL)-4 and IL-10. There was also evidence of innate immunity during the response against Neospora from infected dams, with statistically significant $(p<0.05)$ increases in mean expression of toll like receptors (TLR)-2 on 56 dpi in maternal spleen, LPF, right prefemoral (RPF), left uterine (LUL) and right uterine (RUL) lymph nodes and TLR-9 in retropharyngeal (RLN), LPF and RPF lymph nodes from 28 dpi. Statistically significant $(p<0.05)$ increases in mean TLR-9 were detected in spleen samples from foetuses of infected dams, compared to the foetuses from control animals. Our results show that vertical transmission of the parasite occurred in all infected dams, with their foetuses showing effective Neospora-specific cell mediated, humoral and innate immune responses.
\end{abstract}

\section{Introduction}

Neospora caninum is recognised worldwide as a major cause of abortion and foetal death in farmed ruminants, mainly affecting cattle [1]; though sporadic cases have been reported leading to foetal deaths in sheep [2] and goats [3]. Infection with Neospora can occur either through vertical (transplacental) transmission of the parasite from dam to foetus [4], or through the ingestion of oocysts, shed by infected dogs [5] in contaminated feed, water and pasture (horizontal transmission). Current control strategies for bovine neosporosis mainly

\footnotetext{
* Correspondence: Paul.bartley@moredun.ac.uk

${ }^{1}$ Moredun Research Institute, Pentlands Science Park, Bush Loan, Midlothian, EH26 OPZ, Scotland, United Kingdom

Full list of author information is available at the end of the article
}

involve farm management and bio-security practices (reviewed by Dubey et al.) [1].

It has become clear from natural and experimental data that primary Neospora infections in cattle can lead to abortions and reproductive losses, with cattle infected with Neospora for the first time during pregnancy being 3-7 times more likely to abort than uninfected animals $[6,7]$. Animals can develop a level of natural immunity to the parasite, as cows previously naturally exposed to Neospora are less likely to abort following a secondary infection than pregnant animals with primary infections of the parasite [8]. In addition, multigravidae animals that have aborted due to neosporosis are less likely to abort due to neosporosis during subsequent pregnancies, compared to primigravidae cattle [9]. There is also 
experimental data [10] that demonstrates that exposure of cattle to $N$. caninum prior to pregnancy can protect against the vertical transmission of the parasite following an experimental challenge during mid gestation. However in naturally infected cows that were experimentally challenged on day 70 of gestation, the animals showed protection against foetopathy, but vertical transmission of the parasite still occurred [11]. These results suggest that a protective immune response may be induced that can protect against abortion, however, it may be more difficult to prevent endogenous vertical transmission of the parasite.

The gestational stage and immunological maturity of the foetus at time of infection with $N$. caninum are critical in determining the clinical outcome of infections in pregnant cattle $[10,12,13]$. Infection with $N$. caninum during early gestation leads to high levels of foetal mortality [14] and more severe pathology than infection of cattle with $N$. caninum at mid and late gestation [15]. While an experimental challenge with the parasite at mid gestation did not result in foetal mortality, it did however result in moderate pathology in the foetal central nervous system (CNS) and within the placenta [12]. The foetuses of cattle challenged at mid gestation were shown to be capable of mounting parasite-specific CMI and humoral responses [16]. Observed differences in the maternal immune response to $N$. caninum may have a profound effect on clinical outcome. A study by Bartley et al., [17], showed that in a group of pregnant cows given a similar challenge with $N$. caninum, some of the animals aborted their foetuses whereas other did not. These clinical differences could be related to the cellmediated immune response of the animals to the parasite infection [17].

Neospora-specific cell mediated and innate immune responses are likely to be involved in protection against the parasite, in naturally [18] as well as experimentally infected animals $[10,13,19,20]$. Data from several studies has demonstrated that lymphocyte proliferation and interferon- $\gamma$ (IFN- $\gamma$ ) responses are involved during an immune response to $N$. caninum [11,21-23], and that these responding immune cells tend to be $\mathrm{CD}_{4}^{+} \mathrm{T}$ lymphocytes $[20,24,25]$. Less is known regarding the role of innate immune responses during bovine neosporosis. Work by Boysen et al. and Klevar et al. [26,27] reported that natural killer (NK) cells produced IFN- $\gamma$ during early Neospora infection in calves. Work in mice infected with $N$. caninum has demonstrated that IFN- $\gamma$ production is dependent on myeloid differentiation factor 88 signalling, in a mechanism triggered by interleukin-12 (IL-12) production in dendritic cells [28]. Increased toll like receptor (TLR)-2 expression leads to the maturation of antigen presenting cells such as macrophages and NK-cells and pro-inflammatory cytokine production
[29]. These data show that the innate immune response may be important in the initiation of immune responses to $N$. caninum. Understanding of innate immunity to $N$. caninum will help to improve the design of effective vaccines, which rely on the induction of appropriate immune responses.

In this study the humoral, cell mediated and innate immune responses were examined in pregnant cattle and their foetuses experimentally challenged with live $N$. caninum (NC1 isolate) tachyzoites on day 210 of gestation. This is of particular interest as a primary exposure of cattle to $N$. caninum at late gestation can lead to high levels of transplacental transmission and the birth of persistently infected calves [30], which in turn are at risk of transmitting the parasite to their own offspring. This work will further the understanding of the role of both the maternal and foetal immune responses in cattle following an infection with $N$. caninum at late gestation and help to elucidate the mechanisms involved in disease pathogenesis and parasite transmission in bovine neosporosis.

\section{Materials and methods}

Animals, inoculum and experimental design

Fifteen pregnant cattle all being seronegative for $N$. caninum, Toxoplasma gondii, Bovine Viral Diarrhoea Virus (BVDV), infectious bovine rhinotracheitis and Leptospira spp., were divided into 2 groups (comprising of control cattle $(n=4)$ and animals inoculated with $N$. caninum $(n=11)$ with animals being sacrificed at 14,28 , 42 and 56 days post inoculation (dpi) (Table 1), a full description of the animals is given in Benavides et al. [30]. Parasites for the inoculum were prepared as previously described [31]. Briefly, N. caninum (NC1 isolate) tachyzoites were cultured within Vero cell monolayers. After 4 days the parasites were harvested by scraping the infected cell monolayers and releasing the tachyzoites into the supernatant. The parasites were harvested, counted and adjusted to the required concentration $2.5 \times 10^{8} / \mathrm{mL}$ in phosphate buffered saline (PBS). The $2 \mathrm{~mL}$ dose of parasites was inoculated sc into the animals over the left prefemoral lymph node (LPF) within $1 \mathrm{~h}$ of harvesting the tachyzoites from tissue culture. Uninfected Vero cells $\left(5 \times 10^{7}\right.$ per $2 \mathrm{~mL}$ dose in PBS) were used to inoculate each control animal over the LPF (Table 1). This dose of Vero cells was used, as it was the equivalent number of cells that was present in the parasite inocula.

Table 1 Experimental design

\begin{tabular}{lccccc}
\hline & & \multicolumn{4}{c}{ Post mortem dpi/n = } \\
\hline Group & Inoculum & 14 & 28 & 42 & 56 \\
Infected & $5 \times 10^{8} \mathrm{NC1}$ Tachyzoites & 3 & 3 & 3 & 2 \\
Control & $5 \times 10^{7}$ Vero cells & 1 & 1 & 1 & 1 \\
\hline
\end{tabular}


All animal procedures complied with the Animals (Scientific Procedures) Act 1986 and were approved by the Moredun Research Institute ethics committee.

\section{Samples collected at post mortem}

At post mortem examination, samples of LPF, right prefemoral lymph node (RPF), left uterine lymph node (LUL), right uterine lymph node (RUL), retropharyngeal lymph node (RLN) and spleen were collected from the dams. Samples collected from the foetuses were hepatic lymph node (HLN), mesenteric lymph node (MLN) and spleen. Tissue samples for immunological assays, cell proliferation and cytokine production were collected into sterile wash buffer comprising Hanks Buffered saline solution (HBSS) supplemented with $2 \%$ heat inactivated $(\Delta \mathrm{H})$ foetal bovine serum (FBS) (Labtech International, Ringmer, UK) and $100 \mathrm{IU} / \mathrm{mL}$ penicillin and $50 \mu \mathrm{g} / \mathrm{mL}$ streptomycin (Northumbria Biologicals, Cramlington, UK).

Blood was drawn from dams weekly and at post mortem by jugular venipuncture and from foetuses via the cordal vein, into non-heparinised vacutainer blood collection tubes, and allowed to clot; serum was then separated by centrifugation at $2000 \times g$ for $10 \mathrm{~min}$ and stored at $-20{ }^{\circ} \mathrm{C}$ prior to enzyme linked immunosorbent assay (ELISA) analysis of anti-Neospora IgG.

Sub-samples of the maternal and foetal lymph nodes and spleen were collected for molecular analysis of innate immune responses. Samples were snap frozen on dry ice at post mortem examination, then stored at $-80{ }^{\circ} \mathrm{C}$ prior to RNA extraction, cDNA synthesis and analysis by SYBR green quantitative polymerase chain reaction (qPCR).

\section{Serology}

Analysis of anti-Neospora IgG was performed using a commercially available ELISA kit (IDEXX, Chalfont St Peter, UK) following the manufacturer's instructions. Samples were considered positive with a sample/positive $(\mathrm{S} / \mathrm{P})$ value of $\geq 0.50$. The $\mathrm{S} / \mathrm{P}$ value was calculated using the optical density (OD) results and applying them to the formulae listed below:

Sample OD Result-Negative Control OD ResultPositive Control OD Result-Negative Control OD Result

\section{Preparation of cells for immunological assays}

Single cell suspensions of maternal and foetal lymph node and spleen samples were prepared using the method previously described by Bartley et al. [16]. Briefly; tissues were trimmed to remove excess fat and then chopped into small pieces. These pieces were resuspended in $10 \mathrm{~mL}$ of wash buffer and placed in a stomacher bag (Seward Medical, Northampton, UK) and homogenized for $10 \mathrm{~s}$. The resultant cell suspension was decanted through a double thickness of sterile lens tissue into a sterile universal. The cells were washed twice by repeated centrifugation at $260 \times g$ before being resuspended at a final concentration of $2 \times 10^{6} / \mathrm{mL}$ in cell culture medium (CCM) (Iscoves modified Dulbeco's medium (IMDM) (Gibco, Paisley, UK) supplemented with 10\% $\Delta \mathrm{H}$ FBS and $100 \mathrm{IU} / \mathrm{mL}$ penicillin and $50 \mu \mathrm{g} / \mathrm{mL}$ streptomycin).

\section{Cell proliferation assays}

Single cell suspensions of both lymph node and spleen were treated as previously described by Bartley et al. [16]. In brief, equal volumes of cells $\left(2 \times 10^{6} / \mathrm{mL}\right)$ and antigen were added in quadruplicate to 96 -well round bottom plates (Nunc, Roskilde, Denmark). Watersoluble $N$. caninum tachyzoite antigen (NCA) [10] was used at a final protein concentration of $1 \mu \mathrm{g} / \mathrm{mL}$, the T-cell mitogen concanavalin A (Con A) was used as a positive control at a final protein concentration of $5 \mu \mathrm{g} / \mathrm{mL}$. Vero cell lysate antigen at $1 \mu \mathrm{g} / \mathrm{mL}$ final protein concentration was used as a control antigen and CCM alone was used as a negative control to determine the background level of cell proliferation. The cultures were incubated at $37{ }^{\circ} \mathrm{C}$ in a humidified $5 \% \mathrm{CO}_{2}$ atmosphere for 5 days. The cultures were pulsed with $18.5 \mathrm{kBq}{ }^{3} \mathrm{H}$ Thymidine/well (Amersham Biosciences, Little Chalfont, UK) for the final $18 \mathrm{~h}$, before being harvested onto glassfibre filters (Wallac, Turku, Finland); the cell associated radioactivity was determined using a microbeta Trilux liquid scintillation counter (Perkin Elmer, Wellesley, MA, USA).

Duplicate wells were prepared for each sample; after 4 days incubation at $37{ }^{\circ} \mathrm{C}$ in a humidified $5 \% \mathrm{CO}_{2}$ atmosphere; cell free supernatants were harvested and stored at $-20{ }^{\circ} \mathrm{C}$ prior to analysis by ELISA to quantify cytokine production.

\section{Cytokine responses}

The concentrations of bovine cytokines; IFN- $\gamma$, IL-4, IL-10 and IL-12 present in the cell free supernatant were determined using commercially available cytokine capture ELISA; antibody pairs (Serotec, Oxford, UK) and serial dilutions of appropriate recombinant cytokines were used to create standard regression curves (Table 2).

The ELISA method used for all of the cytokines was based on that previously described by Kwong et al. [33]. In brief, 96-well ELISA plates (Greiner, Stonehouse, UK) were coated with a primary capture antibody $(50 \mu \mathrm{L}$ per well) (Table 2) and incubated at room temperature (RT) overnight. The plates were washed five times using PBS supplemented with $0.05 \%$ Tween 20 (PBS-T) between each step, with the exception of the final 3, 3, 5, 5'tetramethylbenzidine (TMB) - sulphuric acid $\left(\mathrm{H}_{2} \mathrm{SO}_{4}\right)$ 
Table 2 Antibody pairs and standard ranges for bovine cytokines IFN- $\gamma$, IL-4, IL-10 and IL-12 ELISA

\begin{tabular}{|c|c|c|c|c|}
\hline & Primary antibody & Secondary antibody & Standard range & Reference \\
\hline & (Working & $n(\mu \mathrm{g} / \mathrm{mL}))$ & & \\
\hline IFN- $\gamma$ & CC330 $(5 \mu \mathrm{g} / \mathrm{mL})$ & CC302b $(2 \mu \mathrm{g} / \mathrm{mL})$ & $5000 \mathrm{pg} / \mathrm{mL}-10 \mathrm{pg} / \mathrm{mL}$ & \\
\hline $\mid \mathrm{L}-4$ & CC314 $(5 \mu \mathrm{g} / \mathrm{mL})$ & CC313b $(2 \mu \mathrm{g} / \mathrm{mL})$ & $125.00 \mathrm{U} / \mathrm{mL}-0.488 \mathrm{U} / \mathrm{mL}$ & [32] \\
\hline IL-10 & CC318 $(5 \mu \mathrm{g} / \mathrm{mL})$ & CC320b $(2 \mu \mathrm{g} / \mathrm{mL})$ & $11 \mathrm{U} / \mathrm{mL}-0.021 \mathrm{U} / \mathrm{mL}$ & [33] \\
\hline IL-12 & CC301 $(1.25 \mu \mathrm{g} / \mathrm{mL})$ & CC326b (1 $\mu \mathrm{g} / \mathrm{mL})$ & $86.42 \mathrm{U} / \mathrm{mL}-0.013 \mathrm{U} / \mathrm{mL}$ & [34] \\
\hline
\end{tabular}

stage. The plates were blocked at room temperature for $1 \mathrm{~h}$ with PBS-T supplemented with $3 \%$ bovine serum albumin (BSA). Samples and standards (50 $\mu \mathrm{L}$ each) were added and incubated at RT for $1 \mathrm{~h}$. Plates were then coated with an appropriate secondary biotinylated antibody (Table 2) (diluted in PBS-T supplemented with $1 \% \mathrm{BSA})(50 \mu \mathrm{L}$ per well) and incubated at RT for $1 \mathrm{~h}$. Streptavidin- horseradish peroxidiase (HRP) (Dako Cytomation, Glostrup, Denmark) diluted 1:500 in PBS-T 1\% BSA (50 $\mu \mathrm{L} /$ well) was added and incubated at RT for $45 \mathrm{~min}$. Colour was developed by the addition of TMB substrate (Insight Biotech. Ltd., Wembley, UK) $(100 \mu \mathrm{L} /$ well $)$ and incubated for $10-15 \mathrm{~min}$ in the dark. Reactions were stopped by adding $1 \mathrm{M} \mathrm{H}_{2} \mathrm{SO}_{4}(50 \mu \mathrm{L}$ per well). The plates were read at $450 / 650 \mathrm{~nm}$ using a MRX II plate reader (Dynex, East Grinstead, UK). Doubling dilutions of known quantities of appropriate recombinant Ovine (rOv) or Bovine (rBo) cytokines ( $\mathrm{rOv}$ IFN- $\gamma$, rBo IL-4, rBo IL-10 and rOv IL-12) (Moredun Research Institute, Edinburgh, UK) were used to generate a standard regression curve against which the test sample data was fitted. The rOv cytokines were used as standards for the ELISA as good cross reaction between rOv cytokines and bovine cells and antibodies has been previously demonstrated $[34,35]$.

\section{Extraction of RNA from maternal and foetal tissues}

Samples collected and snap frozen on dry ice at post mortem were processed for RNA extraction as follows: approximately $1 \mathrm{~g}$ of frozen tissue was cut into small pieces and placed in a Precelys tissue homogeniser tube (Cepheid, Stretton Derbyshire, UK) containing $1.5 \mathrm{~mL}$ TRI reagent (Applied Biosystems, Carlsbad, CA, USA) and homogenised for $50 \mathrm{~s}$ at $6500 \mathrm{rpm}$ using a Precelys 24 tissue homogeniser, (Cepheid, Stretton Derbyshire, UK). $700 \mu \mathrm{L}$ of the resultant homogenate was split into each of two fresh microfuge tubes containing a further $300 \mu \mathrm{L}$ TRI reagent. The samples were then processed to RNA as per manufacturer's instructions. The final RNA pellet was resuspended in $200 \mu \mathrm{L}$ of RNase free water, the concentration of RNA was determined by spectrophotometry (Nanodrop ND1000); the samples were then stored at $-80{ }^{\circ} \mathrm{C}$ prior to $\mathrm{cDNA}$ synthesis and qPCR.

cDNA synthesis from maternal and foetal RNA samples Following the manufactures instructions, a commercially available high capacity cDNA reverse transcription kit
(Applied Biosystems, Carlsbad, CA, USA) was used to create $2 \mu \mathrm{g}$ of cDNA per sample. Each reaction $(20 \mu \mathrm{L})$ contained $2 \mu \mathrm{L} 10 \times$ RT buffer, $0.8 \mu \mathrm{L}$ dNTP $(100 \mathrm{mM})$, $2 \mu \mathrm{L} 10 \times$ random primers, $1 \mu \mathrm{L}$ reverse transcriptase (50 U/ $\mu \mathrm{L}$ ), $1 \mu \mathrm{L}$ RNase inhibitor, $3.2 \mu \mathrm{L}$ DNase/RNase free water and $10 \mu \mathrm{L}$ RNA $(0.2 \mu \mathrm{g} / \mu \mathrm{L})$; the reaction conditions for the cDNA synthesis reaction were $10 \mathrm{~min}$ at $25{ }^{\circ} \mathrm{C}, 120 \mathrm{~min}$ at $37^{\circ} \mathrm{C}, 5 \mathrm{~min}$ at $80{ }^{\circ} \mathrm{C}$ then held at $4{ }^{\circ} \mathrm{C}$. Following reverse transcription the cDNA was diluted to $400 \mu \mathrm{L}$ in DNase / RNase free water and stored at $4{ }^{\circ} \mathrm{C}$ prior to qPCR analysis.

\section{SYBR green qPCR for glyceraldehyde-3-phosphate} dehydrogenase (GAPDH), toll like receptor-2 (TLR) and TLR-9 To determine whether TLR-2 and TLR-9 expression is being up or down regulated during $N$. caninum infections we examined the expression of the TLRs in both maternal and foetal tissues at different stages following challenge, using the SYBR green qPCR primers and basic protocol described by Menzies and Ingham [36]. All samples were analysed in triplicate, each reaction $(20 \mu \mathrm{L})$ consisted of $10 \mu \mathrm{L}(2 \times$ Fast SYBR green master mix) (Applied Biosystems, Carlsbad, CA, USA), $1 \mu \mathrm{L}$ each forward and reverse primer (10 pmol), $4 \mu \mathrm{L}$ DNase/RNase free water and $4 \mu \mathrm{L}$ cDNA. Analysis was performed under standard conditions including a dissociation step (ABI prism 7000 using sequence detection software (SDS) (v1.2.3) (Applied Biosystems, Carlsbad, CA, USA). The levels of TLR expression were normalised against a reference gene GAPDH, which has been previously shown to be constitutively expressed in bovine tissues [36].

\section{Statistical analysis}

To take into account the increased variability at higher mean values, the maternal and foetal proliferation (cpm) data and cytokine assay data (IFN- $\gamma$ ) were transformed by logarithmic transformation (base 10) prior to the analysis. The TLR-2 and TLR-9 data were adjusted against GAPDH. Separate linear models were fitted to the maternal and foetal proliferative responses, cytokine responses and TLR expression. Due to lack of replication of the control group at each time point, data on the control group were pooled across all time points to estimate the variability. The models included treatment group (comprising five levels: infected group at each of four 
time points and the control group) as an explanatory variable. The model assumes normal distribution for the errors on the analysis scale and this was checked using appropriate plots. The overall statistical significance of the treatment group was evaluated using the $F$-statistic. If the $F$-statistic was statistically significant $(p \leq 0.05)$, two-sided p-values for multiple comparisons between the means of the infected group at each time point and the pooled mean of the control group were obtained; these p-values were then adjusted using a False Discovery Rate (FDR) approach [37] to take into account the problems arising from multiple comparisons. The adjusted $p$-value, denoted in this paper as $p_{f}$, summarises the strength of evidence for there being a genuine difference in a way analogous to a standard $p$-value but allowing multiple testing across different times. Difference in the median maternal serology IgG values between the infected and control group across each time point was assessed using a two sample non-parametric Mann-Whitney test. To take into account multiple comparisons at all time points, the FDR approach as discussed above was used to adjust the p-values. In general, the statistical significance is considered at $5 \%$ level $\left(p_{f}<0.05\right)$, though for some instances where $p<0.05$ but not $p_{f}$, both $p$ and $p_{f}$ values are provided. All statistical analyses were carried out using the $\mathrm{R}$ software version 2.15.2 (R Development Core Team, 2012).

\section{Results}

\section{Proliferative responses from lymph nodes and spleen Maternal}

Infected dams showed increased mean levels of antigenspecific proliferation (counts per minute $(\mathrm{cpm})$ on $\log _{10}$ scale) (Additional file 1) from most tissues examined, compared to the control animals at all the time points, though for most samples no statistically significant differences were seen. On 14 dpi statistically significantly $(p=0.034)$ increased mean levels of antigen-specific proliferative responses were observed in the spleen samples from infected animals, compared to control animals. At the same time point, significantly lower $(p=0.023)$ mean levels of proliferation were observed in the RPF of infected animals (mean, 2.56; 95\% CI, 1.73 to 3.40 ) compared to control animals (mean, 3.99; 95\% CI, 3.16 to 4.82). However, after allowing for multiple testing, the adjusted $\mathrm{p}$-values for these mean comparisons were not statistically significant for either spleen $\left(p_{f}=0.137\right)$ or $\operatorname{RPF}\left(p_{f}=0.09\right)$.

\section{Foetal}

The cell proliferation responses from the foetuses are illustrated in Figure 1. Mean levels of antigen-specific proliferation (cpm on $\log _{10}$ scale) in the spleen were statistically significantly higher in the infected foetuses on
$14 \mathrm{dpi}\left(p_{f}=0.032\right), 28 \mathrm{dpi}\left(p_{f}<0.001\right), 42 \mathrm{dpi}\left(p_{f}<0.001\right)$ and on $56 \mathrm{dpi}\left(p_{f}<0.001\right)$ compared to control foetuses. Significantly increased mean levels of proliferation were observed in HLN samples from infected foetuses on 42 dpi $\left(p_{f}=0.038\right)$ and $56 \mathrm{dpi}\left(p_{f}=0.038\right)$ compared to the control foetuses. There was no evidence of a difference in the mean levels of antigen-specific proliferation in foetal MLN tissue from either group (Figure 1A-D).

\section{Cytokine responses of lymph node and spleen Maternal \\ IFN- $\gamma$}

Increased mean levels of Neospora-specific IFN- $\gamma(\mathrm{ng} / \mathrm{mL}$ on $\log _{10}$ scale) (Additional file 2) were observed in most maternal lymph nodes and spleen samples from infected dams compared to control animals at all the time points. Statistically significantly higher mean levels of IFN- $\gamma$ were observed on 14 dpi $\left(p_{f}=0.021\right)$ in the spleen from infected animals compared to the control animals, while on $56 \mathrm{dpi}$, mean levels of antigen-specific IFN- $\gamma$ in spleen samples from infected animals were lower than those seen in the control animals with marginal statistical significance $\left(p_{f}=0.060\right)$.

\section{IL-4}

Mean levels of antigen-specific IL-4 were higher in all maternal samples from infected animals compared to the control animals, at all of the time points tested (Additional file 3). Statistically significantly increased mean levels of antigen-specific IL-4 were demonstrated on $14 \mathrm{dpi}$ in the spleen $(p=0.028)$ and LPF $(p=0.012)$ of the infected animals compared to the control animals However, when allowing for multiple testing, the mean differences between treatment groups were not statistically significant for either spleen or LPF $(p=0.130$, $p=0.121$ respectively).

\section{IL-10}

Demonstrable antigen-specific IL-10 was only found in the spleen sample from the control animal on $28 \mathrm{dpi}$, all other lymph node and spleen samples from the control animals were below the detection threshold of the ELISA. In the infected animals, on 14 dpi demonstrable levels of antigen-specific IL-10 were seen in spleen samples from 2 of 3 animals. On 28 dpi, IL-10 was produced in 3 of 3 samples of spleen and LUL. On 42 dpi $(2 / 3)$ spleen, (1/3) RUL and RLN samples were shown to be producing IL-10. On $56 \mathrm{dpi}$, IL-10 was only demonstrable in the LUL from 1 of 2 of the infected animals.

\section{IL-12}

All the maternal lymph node and spleen samples tested from the control animals were below the detection 


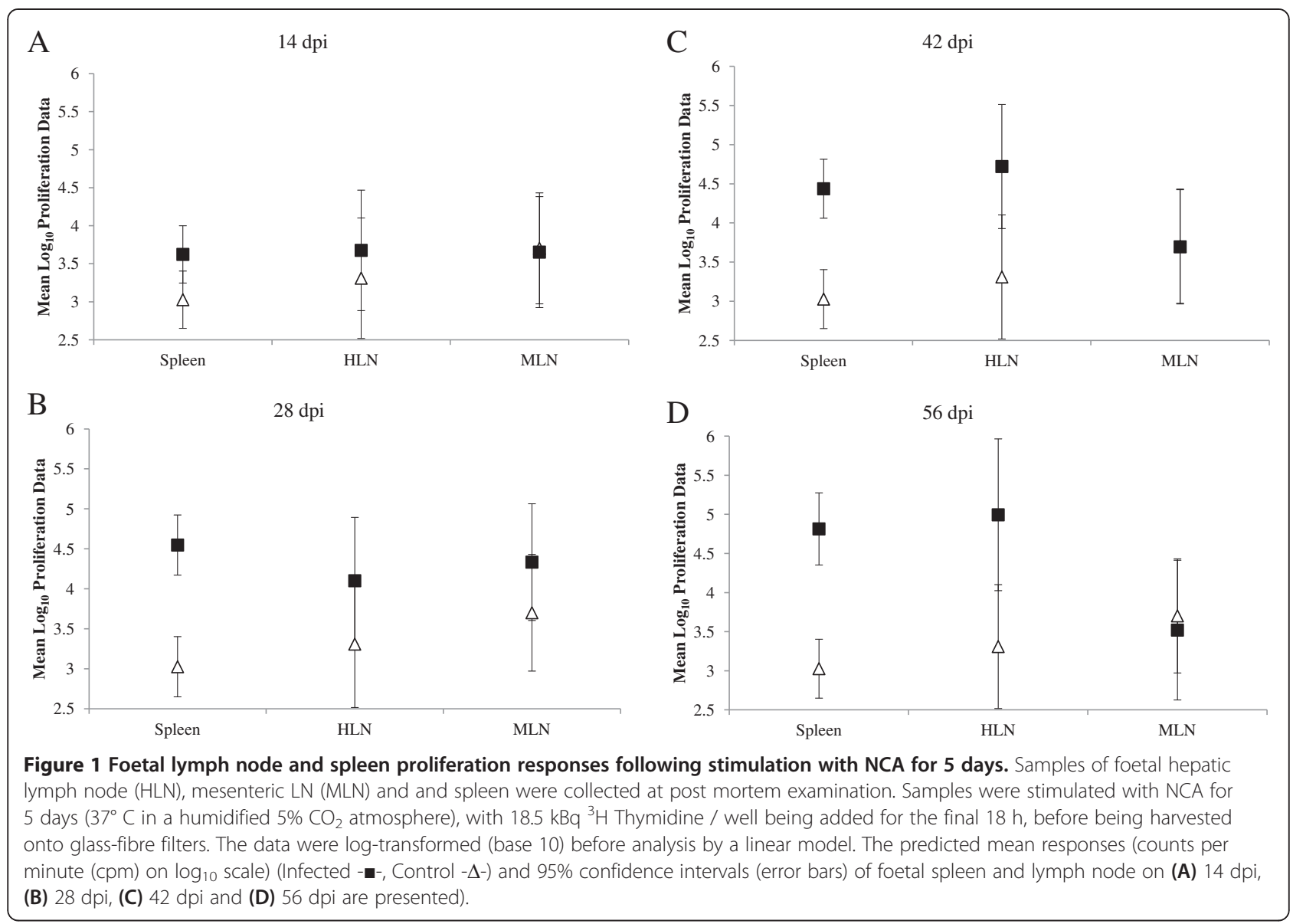

threshold of the ELISA for antigen-specific IL-12. Demonstrable levels of IL-12 were seen in maternal spleen samples from infected animals on 14 and 28 dpi only.

\section{Foetal}

IFN- $\gamma$

The results from the IFN- $\gamma$ ELISA are illustrated in Figure 2A-D. Spleen samples from the foetuses in infected dams showed increased mean levels of antigen-specific IFN- $\gamma$ production $\left(\mathrm{ng} / \mathrm{mL}\right.$ on $\log _{10}$ scale) compared to the foetuses from control animals on 14, 28, 42 and 56 dpi. These mean differences in IFN- $\gamma$ levels of the spleen between control and infected foetuses were statistically significant at all time points $\left(p_{f}=0.018, p_{f}=0.028, p_{f}=0.028\right.$ and $p_{f}=0.018$ for 14, 28, 42 and 56 dpi respectively) (Figure 2A-D). Samples of HLN and MLN from infected foetuses were generally demonstrated increased mean levels of antigen-specific IFN- $\gamma$ production compared to the foetuses from the control animals at all time points, though these differences were not statistically significant (Figure 2A-D).

\section{IL-4}

The infected foetuses showed an increased mean level of production of antigen-specific IL-4 in the spleen compared to the control foetuses on 28, 42 and $56 \mathrm{dpi}\left(p_{f}=0.012\right.$, $p_{f}=0.052$ and $p_{f}=0.012$ respectively) (Additional file 4). On 14 dpi the mean MLN response from the infected foetuses was significantly higher $(p=0.024)$ compared to the control foetuses. However, this mean difference was not statistically significant once allowance was made for multiple testing $(p f=0.114)$. No statistically significant differences were observed between the control and infected foetuses for mean levels of antigen-specific IL-4 produced by foetal HLN samples.

\section{IL-10}

All the samples tested for the control foetuses were below the detection threshold of the ELISA. However, demonstrable antigen-specific IL-10 was seen in spleen samples from the infected foetuses at all time points, on 14 dpi one of three foetuses produced IL-10 and on 28 dpi two of three foetuses produced IL-10. On $42 \mathrm{dpi}$, all infected foetal spleen samples (3 / 3) produced demonstrable antigen-specific IL-10. On $56 \mathrm{dpi}$, spleen and HLN samples from both infected foetuses produced demonstrable levels of antigen-specific IL-10. The mean levels of IL-10 produced by the foetal samples were comparable with maternal samples (data not shown). 


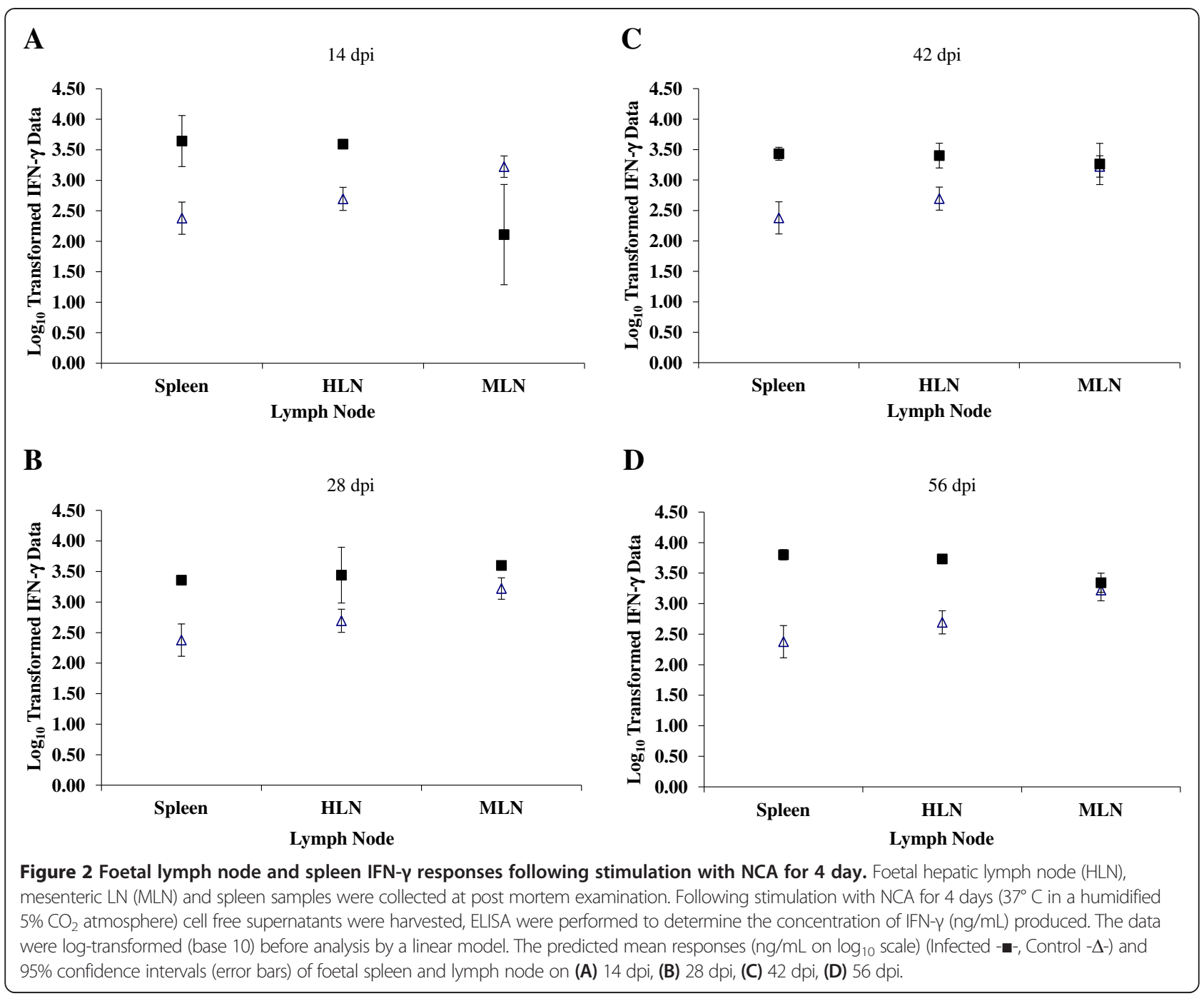

\section{IL-12}

All the samples tested for control foetuses were below the ELISA detection threshold IL-12 at all time points tested. Spleen samples from infected foetuses $(1 / 3)$ produced demonstrable levels of IL-12 on 14 dpi. On 28 and $42 \mathrm{dpi}$, the levels of antigen-specific IL-12 were below detectable levels. However, on 56 dpi, IL-12 was demonstrated from the spleen samples of both infected foetuses. The mean levels of IL-12 produced by the foetal samples were comparable with maternal samples (data not shown).

\section{Expression of TLR-2 and TLR-9 in lymph node and spleen Maternal \\ TLR-2}

Levels of TLR-2 expression were examined at all time points in both control and infected animals. The infected dams demonstrated increased mean levels of TLR-2 expression (pg) in all tissues compared to the control dams at almost all time points. On $56 \mathrm{dpi}$, the infected dams demonstrated statistically significantly increased mean levels of TLR-2 expression in the LPF and RPF compared to the control dams $\left(p_{f}=0.004\right.$ and $p_{f}<0.001$ respectively) (Figure 3C), while the spleen, LUL and RUL samples from the infected animals were all shown to be producing statistically significantly higher mean levels of TLR-2 ( $p=0.035, p=0.024$ and $p=0.018$ respectively) than the control animals (Figure $3 \mathrm{~A}-\mathrm{C}$ ).

\section{TLR-9}

Levels of TLR-9 expression were examined at all time points in both control and infected animals. Infected animals demonstrated increased mean levels of TLR-9 expression (pg) from day 28 onwards in all tissues tested compared to control animals. On 28 dpi statistically significant mean differences were seen between control and 

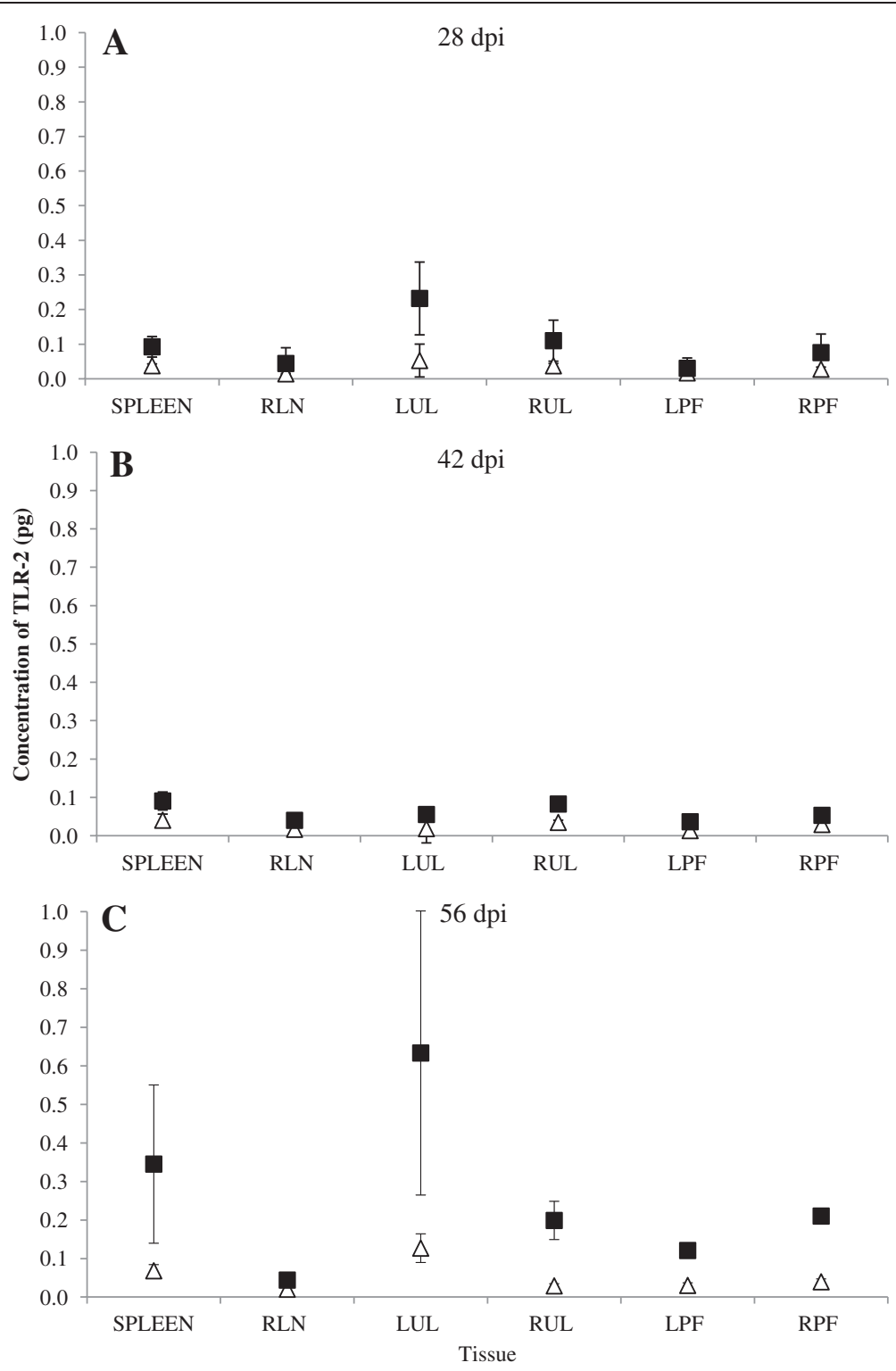

Figure 3 Maternal lymph node and spleen TLR-2 expression. Samples of maternal left prefemoral lymph node (LPF), right prefemoral lymph node (RPF), left uterine lymph node (LUL), right uterine lymph node (RUL), retropharyngeal lymph node (RLN) and spleen were collected at post mortem examination and snap frozen on dry ice. RNA was extracted and used to synthesise CDNA. Levels of expression of TLR-2 were examined with data being normalised against GAPDH expression(pg). The predicted mean responses (pg) (Infected - - --, Control - $\Delta-$ ) and $95 \%$ confidence intervals (error bars) of maternal spleen and lymph node on (A) 28 dpi, (B) $42 \mathrm{dpi}$ (C) $56 \mathrm{dpi}$.

infected animals, in RLN $(p=0.016)$, RPF $(p=0.042)$ and LPF $(p=0.051)$ and in spleen $(p=0.034)$ on $42 \mathrm{dpi}$. While on $56 \mathrm{dpi}$, LPF $\left(p_{f}=0.027\right)$ and RPF $\left(p_{f}=0.028\right)$ from infected animals demonstrated statistically significantly higher mean levels of expression of TLR-9 compared with the control animals (Figure $4 \mathrm{~A}-\mathrm{C}$ ).

\section{Foetal}

\section{TLR-2}

The foetuses from infected animals generally demonstrated increased mean levels of TLR-2 expression (pg)
(Additional file 5) in samples of spleen, HLN and MLN compared to the control foetuses. However, these mean differences were not statistically significant. The mean levels of TLR-2 expression seen in the foetal samples were comparable to those observed in the adult samples.

\section{TLR-9}

When the mean levels of expression of TLR-9 (pg) were examined, statistically significantly increased expression was only observed in the spleen $(p=0.025)$ of the 

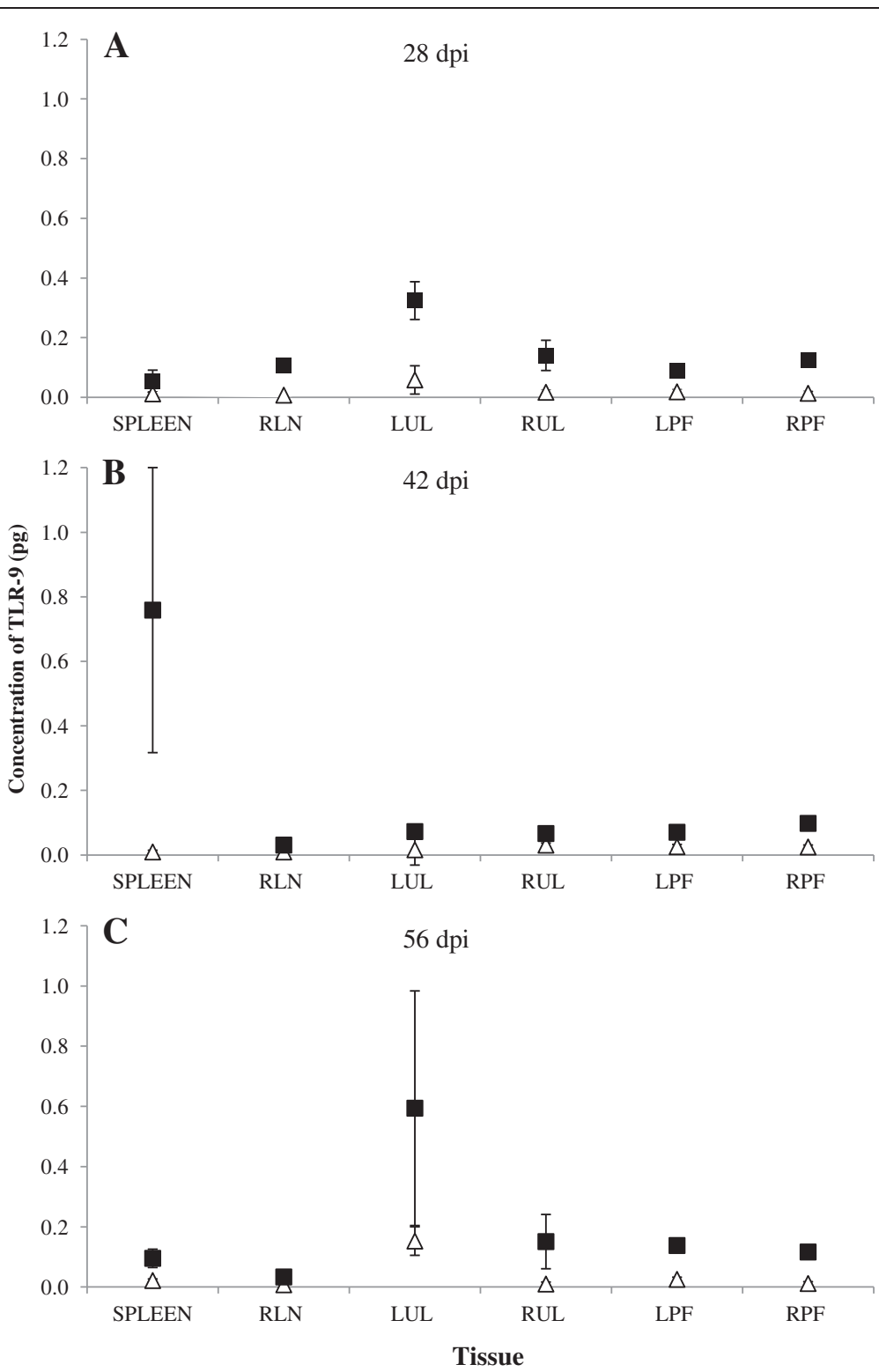

Figure 4 Maternal lymph node and spleen TLR-9 expression. Samples of maternal left prefemoral lymph node (LPF), right prefemoral lymph node (RPF), left uterine lymph node (LUL), right uterine lymph node (RUL), retropharyngeal lymph node (RLN) and spleen were collected at post mortem examination and snap frozen on dry ice. RNA was extracted and used to synthesise CDNA. Levels of expression of TLR-9 were examined with data being normalised against GAPDH expression (pg). The predicted mean responses (pg) (Infected - - -, Control $-\Delta^{-}$) and $95 \%$ confidence intervals (error bars) of maternal spleen and lymph node on (A) $28 \mathrm{dpi}$, (B) $42 \mathrm{dpi}$, (C) $56 \mathrm{dpi}$.

infected foetuses on 42 dpi compared to the control foetuses. However, the mean difference was not statistically significant when adjusted for multiple testing ( $p_{f}=$ 0.101). Generally, the mean expression of TLR-9 of infected foetuses was higher compared to control animals in the spleen, HLN and MLN tissues at all time points. The mean expression of TLR-9 was consistently higher for all samples on $14 \mathrm{dpi}$, with the spleen demonstrating the highest levels of expression from any of the samples tested (data not shown).

\section{Serology}

\section{Maternal}

Following inoculation with $N$. caninum tachyzoites all infected dams seroconverted between 7 and 14 dpi (Figure 5). The mean levels of IgG peaked on $21 \mathrm{dpi}$, the levels of anti-Neospora IgG remained elevated throughout the rest of the experimental period. The mean levels of anti-Neospora IgG in all control animals remained below the 0.50 cut off throughout. The infected animals demonstrated statistically significantly higher median levels of 


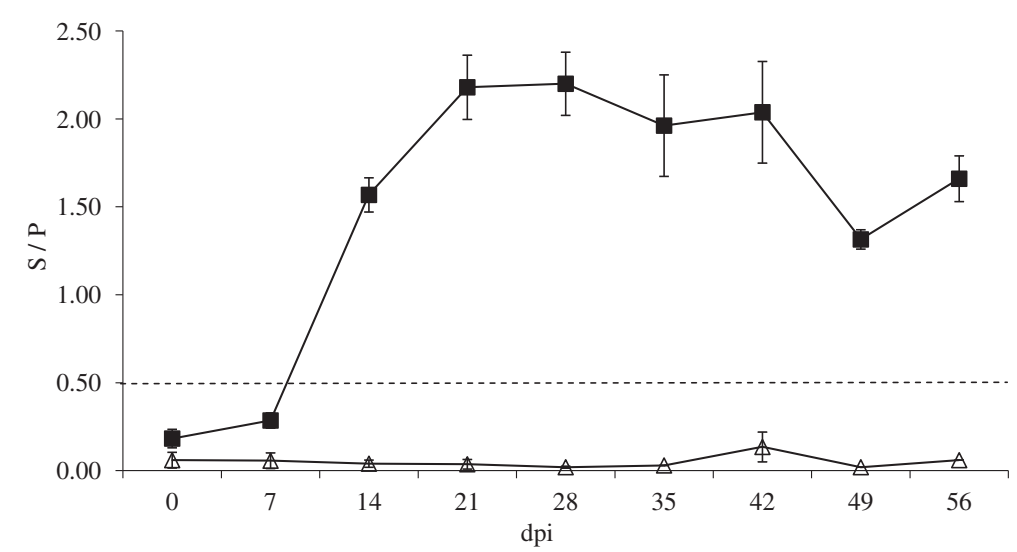

Figure 5 Maternal serology (IgG ELISA) results. Blood was drawn from the dams by jugular venipuncture into non-heparinised vacutainer blood collection tubes and allowed to clot. Serum was separated by centrifugation at $2000 \times \mathrm{g}$ for $10 \mathrm{~min}$ and stored at $-20^{\circ} \mathrm{C}$ prior to analysis of anti-Neospora lgG using a commercially available ELISA kit (IDEXX). Samples were considered positive with a sample / positive (S / P) value of $\geq 0.50$. The S / P value was calculated using the optical density (OD) results. The estimates of means (Infected - - -, Control $-\Delta-$ ) and standard of means (error bars) are presented.

anti-Neospora IgG on 7, 14, 21 and $28 \mathrm{dpi} ;\left(p_{f}=0.054, p_{f}=\right.$ $0.032, p_{f}=0.032$ and $p_{f}=0.032$ respectively) than the control animals. The median levels of anti-Neospora IgG expression in the infected animals remained elevated above the control animals for the remainder of the experiment, though these were not found to be statistically significant.

\section{Foetal}

No anti-Neospora IgG was demonstrable in the samples collected from infected foetuses on 14 and $28 \mathrm{dpi}$. However from $42 \mathrm{dpi}$ onwards all foetuses from infected dams tested positive for anti-Neospora IgG (Figure 6). The levels of anti-Neospora IgG produced by the infected foetuses were comparable to those seen in the adult infected animals. None of the samples tested from control foetuses were considered positive for antiNeospora IgG as they remained below the 0.50 cut off throughout. No statistical comparisons were made due to the properties of the data.

\section{Samples collected from control animal}

Following post mortem examination, samples from the control animal sacrificed on $14 \mathrm{dpi}$ were shown to be positive by $N$. caninum specific ITS1 PCR. Further examination of these samples using primers designed against regions of micro satellite DNA demonstrated

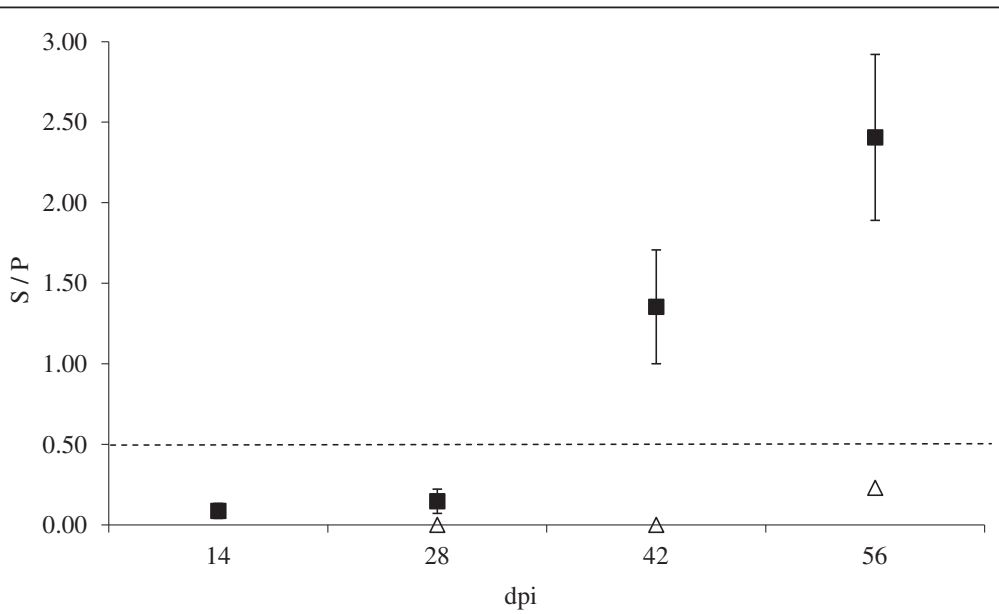

Figure 6 Foetal serology (IgG ELISA results). Blood was drawn from the foetuses at the post mortem examination into non-heparinised vacutainer blood collection tubes and allowed to clot. Serum was separated by centrifugation at $2000 \times \mathrm{g}$ for $10 \mathrm{~min}$ and stored at $-20{ }^{\circ} \mathrm{C}$ prior to analysis of anti-Neospora lgG using a commercially available ELISA kit (IDEXX). Samples were considered positive with a sample / positive

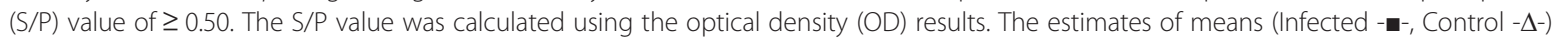
and standard of means (error bars) are presented. 
that the animal was infected prior to the experiment and the infection was due to a strain of $N$. caninum distinct to NC1. As a result of these findings this animal and its foetus were removed from all analysis. Full details of the animal are given in Benavides et al. [30]. This animal was serologically negative for anti-Neospora IgG (using IDEXX ELISA) and had no demonstrable antigen specific responses in the cells from the spleen or any of the lymph nodes tested. All the samples tested from the foetus derived from this dam were also immunologically and PCR negative.

\section{Discussion}

At late gestation (day 210), the foetuses are capable of mounting Neospora specific cell mediated and humoral immune responses, involving lymphocyte proliferation, antigen-specific IFN- $\gamma$, IL-4 and IL-10 production as well as anti-Neospora IgG antibodies. This study has also examined the innate immune response during an experimental infection of cattle, showing significantly increased levels of expression of TLR-2 and TLR-9 in a number of maternal and foetal lymphoid tissues including the spleen, uterine and pre-femoral lymph nodes during the course of the infection.

\section{Maternal CMI responses}

Following challenge there were significant increases in cellular proliferation as well as IFN- $\gamma$ and IL-4 production on 14 dpi in the spleen and peripheral lymph nodes of infected dams and their foetuses, The presence of a CMI response by 14 dpi correlates well with the observation of a circulating parasitaemia observed in all infected dams between $8-14 \mathrm{dpi}$ [30], thus providing a source of antigen for immunological priming to take place. The presence of parasites and parasite antigens is likely to lead to the rapid initiation of an immune response. Our findings agree with work by Rosbottom et al. [38] where pregnant cattle experimentally challenged with $N$. caninum on day 210 of gestation demonstrated increased numbers of $\mathrm{CD} 4+\mathrm{T}$-cells and increased expression of IFN- $\gamma$ and IL-4 mRNA in PBMC, 1-2 weeks following challenge.

\section{Toll like receptors}

Our study shows that TLR-2 and TLR-9 are up regulated in the spleen and lymph nodes of infected animals and their foetuses during $N$. caninum infection. Significant increases in the levels of TLR-2 were not seen in maternal tissues until $56 \mathrm{dpi}$ and TLR-9 on $28 \mathrm{dpi}$. This is later than we would have expected, as much of the current data regarding TLR function shows they are involved in the initiation and activation of immune responses. Work by Werling et al. [39] in cattle has shown strong TLR-2 signalling to be associated with monocytes and other antigen presenting cells (APC), while TLR9 signalling was associated with bovine dendritic cells (DC) and B-cells. Similar finding were observed in mice by where TLR-2 was associated with APC maturation and pro-inflammatory cytokine production $[28,29]$. Cantón et al. [40] observed large numbers of phagocytic cells (in particular macrophages) in resolving lesions in the placenta of infected animals from this experiment from 42 dpi onwards, While on $42 \mathrm{dpi}$ Benavides et al. [30] described lesions in foetal lung and liver characterised by the infiltration of macrophages, lymphocytes and plasma cells. The presence of these cells in the circulatory system may account for the increased levels of TLR-2 expression seen in the spleens of the infected compared to control animals. The increase in TLR-9 expression may be a consequence of increased B-cell activity following the seroconversion of the infected animals and the production of anti-Neospora IgG.

\section{Humoral immune responses}

Infected dams and their foetuses developed strong anti$N$. caninum humoral responses following experimental challenge with the parasite, which continues to suggest a role for antibodies in a protective immune response [41]. Antibody responses were seen in the infected dams from 7 dpi onwards, this coincided with high levels of circulating parasites, however in the foetuses antiNeospora antibodies were not observed until $42 \mathrm{dpi}$. The delay in the generation of a foetal humoral response could be a consequence of the low numbers of parasites crossing the placenta and actively invading the foetuses, until 28 dpi all foetal tissues were PCR negative [30] Though antibodies against $N$. caninum have not been shown to have a definitive role in protection; it is widely believed that they are involved in extracellular tachyzoite neutralisation. Work by Eperon et al. [42] demonstrated increased susceptibility to infection with $N$. caninum of B-cell deficient C57BL/6 $\mu \mathrm{MT}$ mice. While work on the closely related parasite Toxoplasma has demonstrated roles for antibodies in parasite killing by large granular lymphocytes [43] and in opsonisation and intracellular killing of parasites by mononuclear phagocytes [44].

\section{Foetal immune response}

Due to the nature of the ruminant cotyledonary placentae (syndesmochorial placentation), any immune responses detected in the foetus are likely to be induced by an active infection in utero [45]. Under normal circumstances a cotyledonary placentae does not allow the transfer of maternal immune factors including antibodies and cytokines. During our study foetal cell mediated immune responses were detected at $14 \mathrm{dpi}$, which suggests that even during the early stages of the infection 
the parasites crossing the placenta are being dealt with effectively by the foetal immune response, before parasite induced pathology can occur The mild placental pathology being observed, may also be due to there being fewer parasites multiplying in the foetus, therefore there are fewer parasites reinvading the placenta. A reason for this may be that when the parasites reach the placenta they initiate a local maternal immune response. During our experiment increased levels of proliferation and IFN- $\gamma$ production were seen in the uterine lymph nodes of infected animals compared to the controls at 14 dpi. This may in the first instance limit parasite establishment and multiplication reducing the severity of necrosis and pathology in the tissues around the placenta [45], allowing for more efficient parasite clearing. Coupled with the developing foetal immunity could potentially lead to the scarcity of lesions containing parasite antigen found in the CNS of the infected foetuses. A previous experimental study in cattle [46] showed comparable results to this current study; where cattle infected with $N$. caninum (NC Liverpool) at late gestation showed no foetal mortality, though mild placental pathology was observed and parasite DNA was only found sporadically in foetal brain, lung and skeletal muscle.

There is still limited information regarding the development of foetal immune responses during bovine Neospora infections. Following infection at early gestation (Day 70 of gestation) [17] showed that no Neospora-specific CMI responses were generated, though the foetuses were capable of lymphocyte proliferation and IFN- $\gamma$, IL-4, IL-10 and IL-12 production following mitogenic stimulation with Con A from day 84 of gestation onwards, however by mid gestation the foetal immune system is more capable of mounting antigen specific humoral and cell-mediated immune responses [45]. Experimental infections in cattle with Neospora at mid gestation (Day 140 of gestation) have shown significant increases in IFN- $\gamma$, IL-10 and tumour necrosis factor (TNF) expression [19] and Neospora-specific CMI and humoral responses [16] in infected foetuses. While, Andrianarivo et al. [21] showed Neospora-specific immune responses in foetal PBMC at around day 220 of gestation.

During our experiment antigen-specific immune responses were present in the foetuses on 14 dpi demonstrating that parasites crossed the placenta, infected the foetuses and induced an immune response. The numbers of parasites in foetal tissues is likely to be very low, as no positive PCR results were seen at 14 dpi [30]. The foetal spleen processes large volumes of blood, this may result in it potentially trapping parasites as well as circulating leukocytes, allowing more rapid presentation of parasite antigens leading to proliferation and cytokine production before the HLN and MLN have started to respond. The presence of parasite DNA and strong cell mediated immune responses being found in all foetuses would suggest that though the parasite crossed the placenta, the foetal immune response was sufficiently robust to control the parasite resulting in the survival of all infected foetuses to the end of the experimental period.

\section{Conclusions}

The results from this study have demonstrated that following an experimental sc challenge of pregnant cattle with live $N$. caninum tachyzoites on day 210 of gestation; both dams and foetuses mounting Neospora-specific cell mediated, humoral and innate responses. These results show that the stage of gestation is important to disease outcome, with the increasing immunological maturity of the foetus limiting the clinical severity of the infection compared to Neospora infections occurring earlier in gestation. The results show that infections with Neospora at late gestation may lead to congenitally infected but otherwise clinically normal calves [30]. Experimental challenges of pregnant cattle with $N$. caninum tachyzoites allows the detailed study of the host - parasite relationship in bovine neosporosis in a controlled environment, thus improving our understanding of the pathogenesis of the disease.

\section{Additional files}

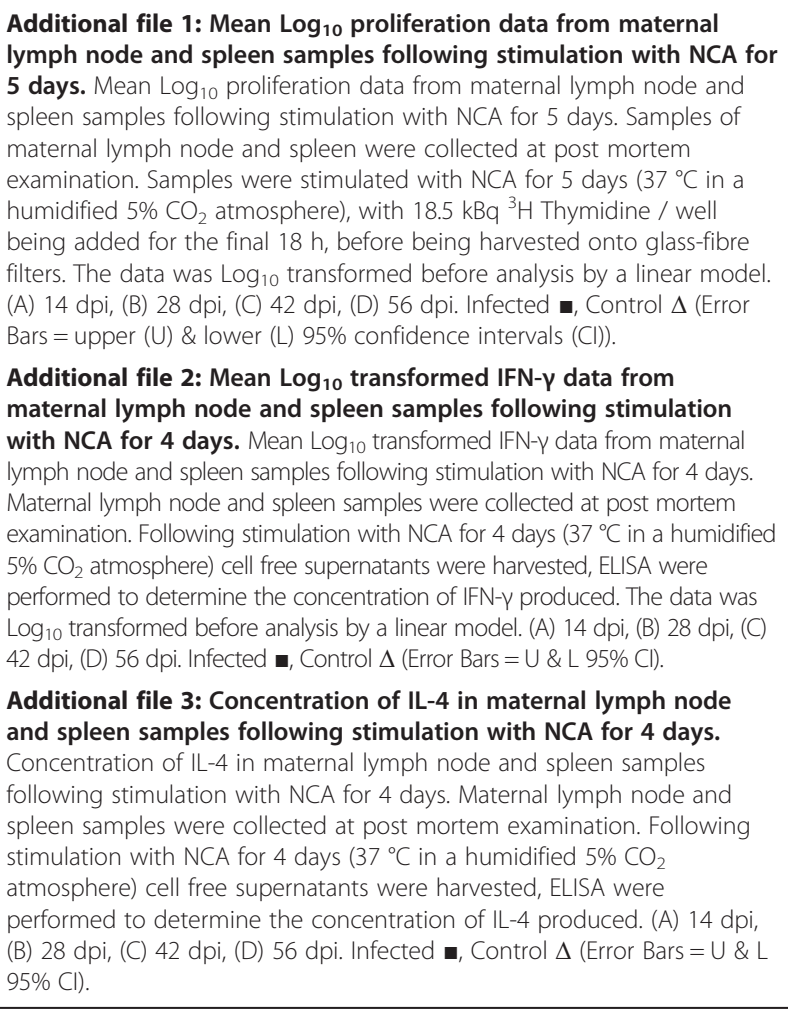


Additional file 4: Concentration of IL-4 in foetal lymph node and spleen samples following stimulation with NCA for 4 days.

Concentration of IL-4 in foetal lymph node and spleen samples following stimulation with NCA for 4 days. Foetal lymph node and spleen samples were collected at post mortem examination. Following stimulation with NCA for 4 days $\left(37^{\circ} \mathrm{C}\right.$ in a humidified $5 \% \mathrm{CO}_{2}$ atmosphere) cell free supernatants were harvested, ELISA were performed to determine the concentration of IL-4 produced. (A) 14 dpi, (B) 28 dpi, (C) 42 dpi, (D) 56 dpi. Infected a, Control $\Delta$ (Error Bars $=U$ \& L 95\% Cl).

\section{Additional file 5: Levels of expression of TLR-2 in foetal spleen,}

HLN and MLN samples. Levels of expression of TLR-2 in foetal spleen, HLN and MLN samples. Samples of foetal lymph node and spleen were collected at post mortem examination and snap frozen on dry ice. RNA was extracted and used to synthesise CDNA. Levels of expression of TLR-2 were examined with data being normalised against GAPDH expression, results are expressed in pg. (A) 28 dpi, (B) 42 dpi, (C) 56 dpi. Infected Control $\Delta$ (Error Bars $=U$ \& L 95\% Cl).

\section{Competing interests}

The authors declare that they have no competing interests.

\section{Authors' contributions}

$\mathrm{PMB}, \mathrm{FK}, \mathrm{JB}$ and EAI made substantial contributions to the conception and design. PMB, MSR, JT, YP, GC, SWM, FC and EAI were involved in the acquisition of data. PMB and MN were involved in the analysis of the data. $P M B, F K, M N$ and EAI have been involved in the drafting and critical review of the manuscript. All authors read and approved the final manuscript.

\section{Acknowledgements}

The authors would like to thank The Scottish Government's Rural and Environment Science and Analytical Services Division (RESAS) for supporting this work and the Bioservices Division of the Moredun Research Institute for care and management of the animals.

\section{Author details}

${ }^{1}$ Moredun Research Institute, Pentlands Science Park, Bush Loan, Midlothian, EH26 OPZ, Scotland, United Kingdom. ${ }^{2}$ Instituto de Ganadería de Montaña (CSIC-ULE), 24346 Grulleros (León), Spain. ${ }^{3}$ Biomathematics \& Statistics Scotland, James Clerk Maxwell Building, King's Buildings, Edinburgh EH9 3JZ, Scotland, United Kingdom. ${ }^{4}$ Instituto Nacional de Tecnología Agropecuaria (INTA), EEA, Balcarce CC276, Argentina.

Received: 13 March 2013 Accepted: 24 September 2013 Published: 3 October 2013

\section{References}

1. Dubey JP, Schares G, Ortega-Mora LM: Epidemiology and control of neosporosis and Neospora caninum. Clin Microbiol Rev 2007, 20:323-367.

2. Bishop S, King J, Windsor P, Reichel MP, Ellis J, Slapeta J: The first report of ovine cerebral neosporosis and evaluation of Neospora caninum prevalence in sheep in New South Wales. Vet Parasitol 2010, 170:137-142.

3. Eleni C, Crotti S, Manuali E, Costarelli S, Filippini G, Moscati L, Magnino S: Detection of Neospora caninum in an aborted goat foetus. Vet Parasitol 2004, 123:271-274.

4. Anderson ML, Reynolds JP, Rowe JD, Sverlow KW, Packham AE, Barr BC, Conrad PA: Evidence of vertical transmission of Neospora sp infection in dairy cattle. J Am Vet Med Assoc 1997, 210:1169-1172.

5. McAllister MM, Dubey JP, Lindsay DS, Jolley WR, Wills RA, McGuire AM: Dogs are definitive hosts of Neospora caninum. Int J Parasitol 1998, 28:1473-1478.

6. Moen AR, Wouda W, Mul MF, Graat EA, van Werven T: Increased risk of abortion following Neospora caninum abortion outbreaks: a retrospective and prospective cohort study in four dairy herds. Theriogenology 1998, 49:1301-1309.

7. Wouda W, Moen AR, Schukken YH: Abortion risk in progeny of cows after a Neospora caninum epidemic. Theriogenology 1998, 49:1311-1316.

8. McAllister MM, Bjorkman C, Anderson-Sprecher R, Rogers DG: Evidence of point-source exposure to Neospora caninum and protective immunity in a herd of beef cows. J Am Vet Med Assoc 2000, 217:881-887.
9. Thurmond MC, Hietala SK: Effect of congenitally acquired Neospora caninum infection on risk of abortion and subsequent abortions in dairy cattle. Am J Vet Res 1997, 58:1381-1385.

10. Innes EA, Wright SE, Maley S, Rae A, Schock A, Kirvar E, Bartley P, Hamilton C, Carey IM, Buxton D: Protection against vertical transmission in bovine neosporosis. Int J Parasitol 2001, 31:1523-1534.

11. Williams DJ, Guy CS, Smith RF, Guy F, McGarry JW, McKay JS, Trees AJ: First demonstration of protective immunity against foetopathy in cattle with latent Neospora caninum infection. Int J Parasitol 2003, 33:1059-1065.

12. Maley SW, Buxton D, Rae AG, Wright SE, Schock A, Bartley PM, Esteban-Redondo I, Swales C, Hamilton CM, Sales J, Innes EA: The pathogenesis of neosporosis in pregnant cattle: inoculation at mid-gestation. J Comp Pathol 2003, 129:186-195.

13. Rosbottom A, Gibney EH, Guy CS, Kipar A, Smith RF, Kaiser P, Trees AJ, Williams DJ: Upregulation of cytokines is detected in the placentas of cattle infected with Neospora caninum and is more marked early in gestation when fetal death is observed. Infect Immun 2008, 76:2352-2361.

14. Macaldowie C, Maley SW, Wright S, Bartley P, Esteban-Redondo I, Buxton D, Innes EA: Placental pathology associated with fetal death in cattle inoculated with Neospora caninum by two different routes in early pregnancy. J Comp Pathol 2004, 131:142-156.

15. Collantes-Fernandez E, Rodriguez-Bertos A, Arnaiz-Seco I, Moreno B, Aduriz G, Ortega-Mora LM: Influence of the stage of pregnancy on Neospora caninum distribution, parasite loads and lesions in aborted bovine foetuses. Theriogenology 2006, 65:629-641.

16. Bartley PM, Kirvar E, Wright S, Swales C, Esteban-Redondo I, Buxton D, Maley SW, Schock A, Rae AG, Hamilton C, Innes EA: Maternal and fetal immune responses of cattle inoculated with Neospora caninum at mid-gestation. J Comp Pathol 2004, 130:81-91.

17. Bartley PM, Wright SE, Maley SW, Macaldowie CN, Nath M, Hamilton CM, Katzer F, Buxton D, Innes EA: Maternal and foetal immune responses of cattle following an experimental challenge with Neospora caninum at day 70 of gestation. Vet Res 2012, 43:38.

18. Andrianarivo AG, Anderson ML, Rowe JD, Gardner IA, Reynolds JP, Choromanski L, Conrad PA: Immune responses during pregnancy in heifers naturally infected with Neospora caninum with and without immunization. Parasitol Res 2005, 96:24-31.

19. Almeria S, De Marez T, Dawson H, Araujo R, Dubey JP, Gasbarre LC: Cytokine gene expression in dams and foetuses after experimental Neospora caninum infection of heifers at 110 days of gestation. Parasite Immunol 2003, 25:383-392.

20. Staska LM, McGuire TC, Davies CJ, Lewin HA, Baszler TV: Neospora caninum-infected cattle develop parasite-specific CD4+ cytotoxic T lymphocytes. Infect Immun 2003, 71:3272-3279.

21. Andrianarivo AG, Barr BC, Anderson ML, Rowe JD, Packham AE, Sverlow KW, Conrad PA: Immune responses in pregnant cattle and bovine fetuses following experimental infection with Neospora caninum. Parasitol Res 2001, 87:817-825.

22. Marks J, Lunden A, Harkins D, Innes E: Identification of Neospora antigens recognized by $C D 4+T$ cells and immune sera from experimentally infected cattle. Parasite Immunol 1998, 20:303-309.

23. Lunden A, Marks J, Maley SW, Innes EA: Cellular immune responses in cattle experimentally infected with Neospora caninum. Parasite Immunol 1998, 20:519-526.

24. Rocchi MS, Bartley PM, Inglis NF, Collantes-Fernandez E, Entrican G, Katzer F, Innes EA: Selection of Neospora caninum antigens stimulating bovine CD4 + ve T cell responses through immuno-potency screening and proteomic approaches. Vet Res 2011, 42:91.

25. Tuo W, Fetterer RH, Davis WC, Jenkins MC, Dubey JP: Neospora caninum antigens defined by antigen-dependent bovine CD4+ T cells. J Parasitol 2005, 91:564-568.

26. Boysen P, Klevar S, Olsen I, Storset AK: The protozoan Neospora caninum directly triggers bovine NK cells to produce gamma interferon and to kill infected fibroblasts. Infect Immun 2006, 74:953-960.

27. Klevar S, Kulberg S, Boysen P, Storset AK, Moldal T, Bjorkman C, Olsen I: Natural killer cells act as early responders in an experimental infection with Neospora caninum in calves. Int J Parasitol 2007, 37:329-339.

28. Mineo TW, Benevides $L$, Silva NM, Silva JS: Myeloid differentiation factor 88 is required for resistance to Neospora caninum infection. Vet Res 2009 40:32.

29. Mineo TW, Oliveira CJ, Gutierrez FR, Silva JS: Recognition by Toll-like receptor 2 induces antigen-presenting cell activation and Th1 
programming during infection by Neospora caninum. Immunol Cell Biol 2010, 88:825-833.

30. Benavides J, Katzer F, Maley SW, Bartley PM, Canton G, Palarea-Albaladejo J, Purslow CA, Pang Y, Rocchi MS, Chianini F, Buxton D, Innes EA: High rate of transplacental infection and transmission of Neospora caninum following experimental challenge of cattle at day 210 of gestation. Vet Res 2012, 43:83.

31. Innes EA, Panton WR, Marks J, Trees AJ, Holmdahl J, Buxton D: Interferon gamma inhibits the intracellular multiplication of Neospora caninum, as shown by incorporation of 3H uracil. J Comp Pathol 1995, 113:95-100.

32. Hope JC, Kwong LS, Thom M, Sopp P, Mwangi W, Brown WC, Palmer GH, Wattegedera S, Entrican G, Howard CJ: Development of detection methods for ruminant interleukin (IL)-4. J Immunol Methods 2005, 301:114-123.

33. Kwong LS, Hope JC, Thom ML, Sopp P, Duggan S, Bembridge GP, Howard CJ: Development of an ELISA for bovine IL-10. Vet Immunol Immunopathol 2002, 85:213-223.

34. Hope JC, Kwong LS, Entrican G, Wattegedera S, Vordermeier HM, Sopp P, Howard CJ: Development of detection methods for ruminant interleukin (IL)-12. J Immunol Methods 2002, 266:117-126.

35. Entrican G, Mclnnes CJ, Rothel JS, Haig DM: Kinetics of ovine interferongamma production: detection of mRNA and characterisation of biological activity. Vet Immunol Immunopathol 1992, 33:171-178.

36. Menzies M, Ingham A: Identification and expression of Toll-like receptors 1-10 in selected bovine and ovine tissues. Vet Immunol Immunopathol 2006, 109:23-30

37. Benjamini Y, Hochberg Y: Controlling the false discovery rate: a practical and powerful approach to multiple testing. J R Stat Soc Ser B 1995, 57:289-300.

38. Rosbottom A, Guy CS, Gibney EH, Smith RF, Valarcher JF, Taylor G, Williams DJ: Peripheral immune responses in pregnant cattle following Neospora caninum infection. Parasite Immunol 2007, 29:219-228.

39. Werling D, Piercy J, Coffey TJ: Expression of TOLL-like receptors (TLR) by bovine antigen-presenting cells-potential role in pathogen discrimination? Vet Immunol Immunopathol 2006, 112:2-11.

40. Cantón GJ, Katzer F, Benavides-Silvan J, Maley SW, Palarea-Albaladejo J, Pang Y, Smith S, Bartley PM, Rocchi M, Innes EA, Chianini F: Phenotypic characterisation of the cellular immune infiltrate in placentas of cattle following experimental inoculation with Neospora caninum in late gestation. Vet Res 2013, 44:60.

41. Moore DP, Leunda MR, Zamorano PI, Odeon AC, Romera SA, Cano A, de YG, Venturini MC, Campero CM: Immune response to Neospora caninum in naturally infected heifers and heifers vaccinated with inactivated antigen during the second trimester of gestation. Vet Parasitol 2005, 130:29-39.

42. Eperon S, Bronnimann K, Hemphill A, Gottstein B: Susceptibility of B-cell deficient C57BL/6 (microMT) mice to Neospora caninum infection. Parasite Immunol 1999, 21:225-236.

43. Erbe DV, Pfefferkorn ER, Fanger MW: Functions of the various lgG Fc receptors in mediating killing of Toxoplasma gondii. J Immunol 1991, 146:3145-3151.

44. Hammouda NA, Abo el-Naga I, Rashwan EA, Hussein ED: Opsonization and intracellular killing of Toxoplasma gondii by human mononuclear phagocytes. J Egypt Soc Parasitol 1995, 25:11-17.

45. Osburn Bl, MacLachlan NJ, Terrell TG: Ontogeny of the immune system. J Am Vet Med Assoc 1982, 181:1049-1052.

46. Gibney EH, Kipar A, Rosbottom A, Guy CS, Smith RF, Hetzel U, Trees AJ Williams DJ: The extent of parasite-associated necrosis in the placenta and foetal tissues of cattle following Neospora caninum infection in early and late gestation correlates with foetal death. Int J Parasitol 2008, 38:579-588.

doi:10.1186/1297-9716-44-9

Cite this article as: Bartley et al.: Development of maternal and foetal immune responses in cattle following experimental challenge with Neospora caninum at day 210 of gestation. Veterinary Research 2013 44:91.

\section{Submit your next manuscript to BioMed Central and take full advantage of:}

- Convenient online submission

- Thorough peer review

- No space constraints or color figure charges

- Immediate publication on acceptance

- Inclusion in PubMed, CAS, Scopus and Google Scholar

- Research which is freely available for redistribution

Submit your manuscript at www.biomedcentral.com/submit 